\title{
Aspirational Ethics as a Contributing Factor in Engineering Students' Ethical Awareness and Behavior
}

\author{
Zuraida Ahmad ${ }^{\text {* }}$, Noraini Mohamed Noor ${ }^{2}$, Siti Fauziah Toha ${ }^{3}$, Nurul Fadzlin \\ Hasbullah $^{4}$, Ali Sophian ${ }^{3}$ and Maizirwan $\mathrm{Mel}^{5}$ \\ ${ }^{I}$ Department of Manufacturing and Materials Engineering, Kulliyyah of Engineering, \\ International Islamic University Malaysia, Kuala Lumpur, Malaysia \\ ${ }^{2}$ Department of Science in Engineering, Kulliyyah of Engineering, \\ International Islamic University Malaysia, Kuala Lumpur, Malaysia \\ ${ }^{3}$ Department of Mechatronics Engineering, Kulliyyah of Engineering, \\ International Islamic University Malaysia, Kuala Lumpur, Malaysia \\ ${ }^{4}$ Department of Electrical and Computer Engineering, Kulliyyah of Engineering, \\ International Islamic University Malaysia, Kuala Lumpur, Malaysia \\ ${ }^{5}$ Department of Biotechnology Engineering, Kulliyyah of Engineering, \\ International Islamic University Malaysia, Kuala Lumpur, Malaysia \\ *Corresponding Author: zuraidaa@iium.edu.my
}

\begin{abstract}
As ethical behavior is a part of engineers' professional identity and practice, developing ethical behavior skills in future engineers is a vital component of the engineering curriculum. There are already established instructional methods to teach engineering ethics (EE), however, it is concentrated on ethical awareness, and little attention has been given to how this will affect the ethical behavior. Even though students are capable of exercising ethical judgment, it does not mean that they are ethically literate or likely to act ethically. The assessment of engineering ethics cannot be conducted based on ethical judgment, because the ethical awareness of some engineers has not translated into ethical behavior. An alternative instructional method for measuring the ethical behavior is required to see how the ethical awareness given in the classroom setting is translated to the actual ethical behavior. Therefore, the focus of this paper is to propose an instructional method that correlates with both ethical awareness and ethical behavior, through aspirational ethics which require the students to contribute to the society. This method integrates the theory of morals and values, ethical and unethical conduct, code of practices of an engineer, ethics with the environment, and the responsibility of the engineer for the safety of everybody. Students' ethical behavior in the society will be demonstrated through the University Social Responsibility (USR) projects. From these projects, the students' ethical behavior is assessed by their peers, beneficiaries that they are serving, as well as by the educators, regarding their ethical conduct. This will be the tools to observe the degree of correlations between the ethical awareness instilled and behavior manifested. Applying these instructional methods will allow educators to build confidence and trust in their students' ability to build a professional identity and be prepared for the engineering profession and practice.
\end{abstract}


Keywords: Ethical behavior, Engineering ethics, Ethical awareness, Instructional methods, University Social Responsibility projects

\section{INTRODUCTION}

A growing number of engineering curricula are emphasizing ethics. There are more and more engineering ethics electives being offered in Malaysia's Institutes of Higher Learning (IHL). Some have integrated engineering ethics courses into professional ethics or technology and society courses; others have included it as a stand-alone subject. Furthermore, the Engineering Accreditation Council (EAC) under the Board of Engineer Malaysia requires engineering programs to include ethical and social concerns in the program outcomes (PO).

Two reasons account for this growing interest in delivering topics in ethics to the students. The first, and most obvious, fact is that ethical and social issues pertinent to engineers must be learned, as with all other disciplines. Engineering professionals can only become reflective practitioners if they understand what their professional activities mean for citizens' health and welfare. Second, understanding engineering ethics that places the safety, health, and welfare of the public first is helpful, but it does not provide sufficient guidance in practice. An engineer is regularly confronted with ambiguities and conflicts in daily work due to the conflict between the dictates of technical knowledge, capital requirements, and labor demands.

\section{Challenges in Teaching Engineering Ethics (EE)}

The EE in engineering education plays a crucial role in developing ethical decision-making skills in our future engineering leaders and innovators. The question, however, lies in how the engineering educators should accomplish this goal. The evolution of the pedagogical frameworks of EE education can be observed over many decades, and it moves primarily towards the utilization of case studies, codes of ethics and introduction to moral theory (Basart, 2015; Bairaktarova \& Woodcock, 2016; A Workshop on Ethics and Engineering Education, 2019). Thus, in teaching moral judgment and ethical reasoning, the educators of EE often place emphasis on reasoning and moral judgment, with little attention being devoted to how this will translate into ethical behavior (Balakrishnan, 2016). There are articles claiming that more than $60 \%$ of engineering students in Malaysia commit unethical behavior at least once in their duration of studies (Ahmad et al., 2017; Rodzalan \& Saat, 2016), and the concern is that ethical problems continue to occur in the working environment as well. Past studies have shown a significant relationship between poor behavior during learning and unethical behavior at the workplace (Ahmad et al., 2017; Lawson, 2004). 


\section{Models and Instructional Strategies for Teaching Engineering Ethics (EE)}

Generally, ethics is not a mandatory course in the engineering curricula in many countries. Despite this, engineering graduates are expected to possess both ethical and professional qualities. It is listed in the ABET criteria of accrediting engineering programs, 20202021(Criteria for Accrediting Engineering Technology Programs, 2020). This trickles down to the local accrediting body in Malaysia, whereby the Engineering Accreditation Council (EAC) in their Engineering Programme Accreditation Standard 2020, listed ethics as one of 12 outcomes required in an undergraduate engineering programme, even though teaching engineering ethics is still not a high priority in engineering education (Engineering Accreditation Council (EAC), 2020). Research shows that EE education is ineffective, showing no evidence of gains among freshmen and seniors in terms of ethical decision-making, which implies that the curriculum fails to prepare students for ethical challenges they will encounter in the workplace (Clancy et al., 2016).

There was a comprehensive review of engineering education conducted by a team of scholars, with a large sample across the globe, which provided a comprehensive analysis of how undergraduate engineering education supports students' ethical development (Ozaktas, 2011). Analyses of strengths and weaknesses of the existing approaches suggest that engineering programs lack accurate and reliable approaches to teaching and assessing professional ethics.

The stand-alone ethics course throughout the semester, with multiple-credit hours, focuses on discipline-specific issues and is offered by the philosophy department, covering the introduction to moral philosophy and theories of ethics only, which to some extent diverts the interest of the engineering students (Herkert, 2001). Those engineering schools that are attempting to imbue morality and ethics across the EE curriculum, mainly expose students to discussions on professional responsibilities and ethics, and it requires commitment and collaboration from all educators in the faculty to incorporate ethics discussions within traditional non-ethics courses (Weil, 2003). Unfortunately, in this instructional mode, the ethics component is not credited and receives no grading, which may diminish their importance and minimize the degree of seriousness they receive.

The case-based instructional method appears to be the most common pedagogical method in EE education. It is common for case studies employed in EE to be complex, dynamic, and not transparent, and this applies equally to ethics and engineering cases. The events in these cases, however, occurred long ago on the other side of the world. Students are asked to assess ethical decisions based on an established code of ethics, rather than using their own experiences to determine what is right and wrong (Loendorf, 2009).

An education in EE is piecemeal and lacks agreement regarding content or approach, rendering the students to be unequipped to make ethical decisions once they are in the workplace. Research reveals that student's knowledge of ethics leaves much to be desired (Harding et al., 2013). This might be due to students' receiving superficial understanding of the meaning of ethics, or they may lack mastery of what they learned. Another plausible explanation 
is that educators fail to utilize the appropriate methods of ethics instruction and assessment. They usually make their own decisions about the pedagogical methods; however, the curriculum is developed at the faculty level (Miñano et al., 2016). There are also practices adopting "alternative pedagogies", such as service learning, that offers an opportunity to integrate ethics directly into the engineering content (Zoltowski et al., 2014). Engineering faculty have also been creative in finding ways of including ethics directly in their subject areas, such as immersive engagement for community experience through seeking opportunities for learning communities to work on local community projects, examining and practicing subtle as well as deliberative arguments in favor of potentially problematic technologies in the context of ethics and writing courses (Bairaktarova \& Woodcock, 2016; Zoltowski et al., 2014; Kiser et al., 2009).

Most of the assessment made for the EE course is heavily influenced by the notation of moral reasoning, whereby the judgment is based on what is right and what is wrong. Kohlberg's framework of six stages of moral reasoning: avoid punishment, self-interest, "good boy" attitude, law and order morality, social contract principle, is among the contemporary tools used (Bairaktarova \& Woodcock, 2016; Stockton-Tillman, 2017). Students respond to scenarios depicting ethical dilemmas, and their responses are used to categorize them in accordance with Kohlberg's framework. Reliable assessment of moral development obtained by this framework, however, may be appropriate for individuals, but not adequate for influencing moral obligations, attitudes toward moral issues of behavior, or situational factors such as social norms and perceived control over ethical behavior that are normally faced by the engineers in the workplaces.

The goal of engineering ethics education is to teach, assess and empower ethical behavior. Education in EE has traditionally been based on simply assessing students' basic ethical reasoning. Research shows that the link between ethical reasoning and ethical behavior is minimal (Balakrishnan et al., 2018). It is argued that the measurement and instruction of ethical awareness, intentions, and behavior are what is needed in engineering ethics education, rather than just instruction and assessment of ethical reasoning. Therefore, an alternative pedagogy is needed to ensure that EE education benefits the engineering graduates, so that they can perform as ethical engineers later and serve the society with proper ethical decisions.

A study comparing Japanese engineering students with Malaysian engineering students, shows that EE education objectives were achieved and students' attitudes toward socio-ethical issues in engineering were significantly higher and more positive in Japan, due to its wellstructured, integrated, and innovative pedagogy for teaching ethics. It has a great impact on the students' attainment of education objectives and their attitude towards EE education (Bruce \& Roli, 2001).

\section{Aspirational Ethics in Engineering Education}

An important distinction in engineering ethics, as part of the subject that is normally taught to the students, is between preventive ethics, which consists of guidelines for preventing public 
harm, and aspirational ethics that consists of guidelines and motivating considerations for using one's professional expertise to promote human well-being. In a profession, preventive ethics are governed by rules and are mandatory. When it comes to implementing aspirational ethics, a professional has greater discretion in terms of determining what is involved and when and how to implement them. Aspirational ethics should be given a greater prominence in professional ethics, even though preventive ethics remain important. There are four main types of aspirational ethics that can be distinguished based on their increasingly direct focus on people's well-being: 1) acts exhibiting exemplary Professional Excellence; 2) supererogatory preventive acts; 3) good works; and 4) altruistic engineering acts. On the other hand, four virtues can be identified as having special importance in motivating and guiding aspirational ethics: 1) aspiration to professional excellence; 2) respect for nature; 3) techno-social sensitivity; and 4) benevolence (Harris, 2013).

There will be different approaches in teaching EE that embrace aspirational ethics. Even merely teaching one or the other approach will not help students become ethical professionals, because norms, rules, or standards can only guide action in specific situations, and instances without value premises result in ethical relativism instead of sound judgements (Wijesinghe \& Jayawardane, 2018). The teaching of both approaches together may improve the situation, but it does not eliminate the issue of ambiguity that may arise when applying these to cases of norms, rules, and standards - ambiguities that cannot always be clarified.

Understanding the need to have a good approach for engineering ethics that incorporates the aspirational approach, the Kulliyyah of Engineering (KoE), International Islamic University Malaysia (IIUM), has reviewed its EE stand-alone course, inculcating the university social responsibility projects as one platform to promote this type of ethic, in the course content. Therefore, this paper reports the case study in IIUM on aspirational ethics as a self-motivating factor for Engineering Student's Ethical Awareness and Behavior.

\section{BACKGROUND OF ENGINEERING ETHICS IN KULLIYYAH OF ENGINEERING}

In the Kulliyyah of Engineering (KoE), International Islamic University Malaysia (IIUM), ethics has been introduced for more than 15 years as a stand-alone subject in all engineering programs. The total number of students who took the subject per semester lies in the range of 350-450. As a Kulliyyah-required subject, it was presented from the Islamic perspective and taught by educators who have a strong background in Islamic Revealed Knowledge. This was practiced for quite some time until the EAC came out with a regulation that only engineering background educators teach the subject.

\section{Previous Engineering Ethics Course in Kulliyyah of Engineering}

The latest course title for this ethics course, before being reviewed and embedded with the aspirational ethics component, was "Engineering Ethics, Safety, and Environment" (GENE 4300) Engineering studies incorporate the study of religion, ethics, and key themes of humanity 
in nature. It focuses on engineering professional ethics from an Islamic perspective, and emphasis is given to preventive ethics. The central theme of this course is to relate Engineering Professionalism to Islamic ethical foundations. Occupational Safety and Health Administration (OSHA) and the variety of industrial hazards and disasters that could affect humans and the environment are also emphasized within the course. Furthermore, the course is developed to instill a sense of religious and ethical awareness in future Muslim engineers. As a Kulliyyahrequired subject, it was viewed from an Islamic perspective, and taught by educators well-versed in Islamic Revealed Knowledge. This practice was sustained for quite some time until the EAC issued a new regulation that only educators with an engineering background could teach the subject. The KoE has taken the approach of designing the course to be taught by two educators, one covering Islamic Knowledge in the earlier part, and the other dealing with engineeringrelated matters in the second part of the semester. The activities involved traditional methods of teaching, with a theory-based approach, including discussions as well as standard case studies from past records.

\section{The Newly Developed Engineering Ethics Course}

In the process of designing the EE course, the faculty has considered all the comments from all the stakeholders and industry advisory panels (IAP), as well as the Engineering Accreditation Panel, and the Kulliyyah and University aspirations. Table 1 depicts the major points suggested to be included in the course.

\section{Table 1}

Feedback and Policies from the Stakeholders

\begin{tabular}{ll}
\hline \multicolumn{1}{c}{ Mechanism } & \multicolumn{1}{c}{ Suggestion Considered } \\
\hline $\begin{array}{l}\text { EAC requirement } \\
\text { (Balakrishnan, 2016) }\end{array}$ & $\begin{array}{l}\text { Under the exposure to engineering Practice in the EAC } \\
\text { Manual 2020, the Council is asking that courses on } \\
\text { professional ethics and code of ethics must be introduced in } \\
\text { all engineering programs. } \\
\text { - }\end{array}$ \\
& $\begin{array}{l}\text { Students to be aware of their responsibility to be registered } \\
\text { with the Board of Engineers upon graduation. }\end{array}$ \\
\hline IAP (Ahmad et al., 2017) & - Ethical conduct for safety of the people. \\
& $\begin{array}{l}\text { Experiential learning with industry-experienced people } \\
\text { sharing knowledge on ethical conduct and risk assessment } \\
\text { and safety. }\end{array}$ \\
\hline
\end{tabular}


Table 1 (continued)

\begin{tabular}{|c|c|}
\hline Mechanism & Suggestion Considered \\
\hline $\begin{array}{l}\text { Kulliyyah and University } \\
\text { aspirations (A Workshop } \\
\text { on Ethics and } \\
\text { Engineering Education, } \\
\text { 2019) }\end{array}$ & $\begin{array}{l}\text { Humanizing elements adopting the Sejahtera Framework } \\
\text { (SAF) in the subjects, comprising the Kulliyyah and } \\
\text { University Mission and Vision, Maqasid As-Shariah, } \\
\text { Falsafah Pendidikan Kebangsaan (FPK) and KhAIR } \\
\text { (Khalifah, Amanah, Istiqamah and Rahmatan lil'alamin) } \\
\text { attributes. } \\
\text { - Need to include both affective and cognitive domains } \\
\text { covering the Programme Outcome related to Society, } \\
\text { Sustainable Development and Ethics (PO6, PO7, and PO8). }\end{array}$ \\
\hline $\begin{array}{l}\text { Demand from other } \\
\text { stakeholders (A } \\
\text { Workshop on Ethics and } \\
\text { Engineering Education, } \\
\text { 2019; Balakrishnan, } \\
\text { 2016; Ahmad et al., } \\
\text { 2017) }\end{array}$ & $\begin{array}{l}\text { Value-added knowledge like creative thinking, people } \\
\text { management, and coordination, judgment, and decision- } \\
\text { making. }\end{array}$ \\
\hline $\begin{array}{l}\text { Global perspective } \\
\text { (Balakrishnan, 2016; } \\
\text { Ahmad et al., 2017) }\end{array}$ & $\begin{array}{l}\text { - It needs to be embedded with Fourth Industrial Revolution } \\
\text { (IR 4.0) themes, Sustainable Development Goals (SDG) as } \\
\text { well as Global Citizenship values. }\end{array}$ \\
\hline
\end{tabular}

From the suggestions given by all the parties, the course framework was constructed based on Figure 1, taking also into consideration the IIUM's aspiration, which is documented in the Sejahtera Academic Framework (SAF) (Borhan et al., 2021). The direction set for the course, anchored upon aligning and realizing that each human being is created as the servant and as Khalifah of Allah at the same time, being entrusted with an Amanah to govern this world; and some have been given the ability and opportunity by Allah SWT to be in the University and taking the engineering course to be an engineer. In showing gratitude, encouragement needs to be given to the students to master the knowledge holistically and portray good character and behavior and become exemplars to others through the study of ethics. As they will graduate and work in challenging environments, students need to be made aware of the protection and the rights that they have in this profession-being a responsible engineer, and under the concept of mercy to all mankind (Rahmtan Lil 'Alamin), the students need to be made aware of their role and responsibility to contribute to the well-being of humanity in a safe environment through aspirational ethics. Ethics and character building are topics that are not merely to be understood but must also be internalized and demonstrated. This framework can then be incorporated into the course content, as in Table 2. 


\section{Figure 1}

Framework for the Newly Developed Engineering Ethics Course

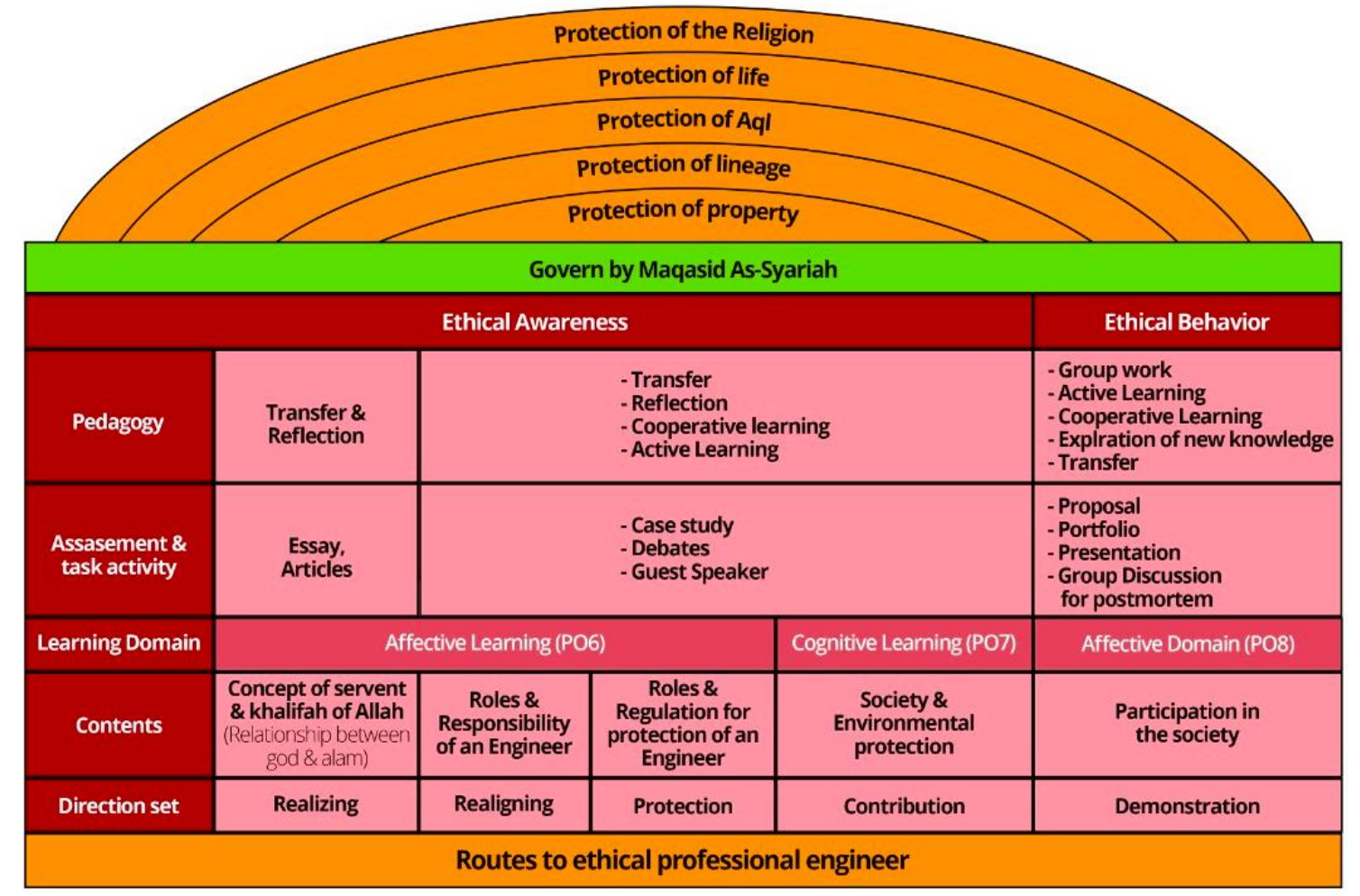

Table 2

Contents for the Newly Developed Engineering Ethics Course

\section{Contents}

\section{Activities}

\section{Concept of khalifah: Relationship with Creator; Human being and Class 'Alam, Insan Sejahtera (FPK): IIUM/KoE Vision and Mission discussion, (Maqasid Syariah) survey}

Role and responsibility of engineers; Attributes of engineers: The Class debates, importance of engineering ethics; Ethical Theories; Ethics from forum the Islamic Perspective; Ethical Conduct and Engineering Ethics

Code of conduct for Engineers; Guideline for Code of Role play, Professional conduct; Engineers Act 1967 (Amendments 2015); presentation Case studies

Professionalism: The concept of Professionalism in relation to Class Itqan (Perfection) and Ihsan (goodness); Criteria for discussion, professionalism: - Accountability, Honesty and Integrity, talks, sharing Specialized knowledge and competency, Respect and empathy, session etc 
Table 2 (continued)

Contents Activities

An unethical scenario in the workplace: Organizational structure, Class its policy, and the possibility of misconduct: - Confidentiality, discussion, conflict of interest, corruption, and bribery, piracy, and copyright role play issues

\begin{tabular}{|c|c|}
\hline $\begin{array}{l}\text { Management crises: Conflict between the manager and the } \\
\text { engineers, whistleblowing; Cases Study }\end{array}$ & $\begin{array}{l}\text { Sharing } \\
\text { sessions, case } \\
\text { study } \\
\text { evaluation }\end{array}$ \\
\hline $\begin{array}{l}\text { Law of contract, Akta Suruhanjaya Pencegahan Rasuah Malaysia } \\
\text { (SPRM), Employment Act and Regulation, Bankruptcy Act, } \\
\text { Cyber Law, }\end{array}$ & $\begin{array}{l}\text { Talks, video } \\
\text { presentation }\end{array}$ \\
\hline $\begin{array}{l}\text { Engineers on Safety and Health issues in the } \\
\text { workplace: Detection and identification of hazards, Possibilities } \\
\text { for the prevention of hazards and risk assessment }\end{array}$ & $\begin{array}{l}\text { Site visits, class } \\
\text { discussion, } \\
\text { sharing session }\end{array}$ \\
\hline $\begin{array}{l}\text { Engineers on Safety and Health issues in the workplace: good } \\
\text { laboratory practice, Practical experiences and sources of error }\end{array}$ & $\begin{array}{l}\text { Site visits, class } \\
\text { discussion, } \\
\text { sharing session }\end{array}$ \\
\hline $\begin{array}{l}\text { Engineers on environmental Protection: Conception of } \\
\text { conservation and utilization of resources: land, water, and air. A } \\
\text { solution to global warming problems, Managing waste and } \\
\text { recycling and renewable energy, environmental impact } \\
\text { assessment, and environmental acts }\end{array}$ & $\begin{array}{l}\text { Video } \\
\text { presentation, } \\
\text { class discussion }\end{array}$ \\
\hline
\end{tabular}

Key concepts of sustainability and issues, SD Pillars- Social, Discussion, Environmental and Economic: Sustainable Issues and Solutions, forum, video Ethical Challenges in IR 4.0: presentations

Contributions of engineers to society - Aspirational Ethics Students' presentations

USR and Analyses on the ethical issues Mini projects

Registration of Engineers with Board of Engineers (BEM), Route Talks and to be a Professional Engineer, sharing experience 


\section{METHODOLOGY}

\section{Research Design and Instrumentation}

The study employed the descriptive survey method to gather students' perceptions on two versions (the previous and reviewed versions) of the Engineering Ethics course offered in KoE. The instrument used in the study was adapted from Borhan et.al. (2021), a structured questionnaire of 9 statements related to students' perceptions of the course contents (students' interest and course coverage), and educators' approach of the course (approach to the contents and deliveries). In the structured questionnaire, a qualitative question to explain their feelings on the EE course taught was also included. It allowed students to freely express their perception of the subject, while suggesting some improvement for it as well. Only a few of the written answers were selected to be included in this research article. The same instrument was distributed to the students who took the newly developed EE course, but with an addition of a question on their satisfaction of the humanitarian project known as the University Social Responsibility (USR) project, which is one of the elements for aspirational ethics.

\section{Data Collection}

The survey for the students who took the previous EE course (GENE 4300) were administered in Semester 1, Session 2019/2020, involving 80 students from two sections out of the six sections. Meanwhile, the second survey for the students who took the newly developed EE course (GENE 4301) was executed for two of the six sections of the students taking the course in Semester 2, Session 2019/2020, and for all the sections in Semester 1, Session 2020/2021. A total of 450 students were involved in the second survey. The educators for the EE courses were briefed on the new instructional methods including the direction, task activities and assessments before the briefing was given to the students at the beginning of the semester. Educators were given freedom on how to conduct the class, however, all the classes had similar content and distribution of marks for the assessments. Students were also reminded to start looking for a humanitarian project to be executed in their week 12 of studies, and all the marks related to these humanitarian projects, which were categorized as part and parcel of aspirational ethics, were considered as final assessment (including proposals, portfolios and presentations). All the assessments were in the rubric forms covering ethical aspects such as honesty, respect, responsibility, fairness, level of empathy, communications, risk assessment, which were distributed across the components of the final assessment. A post-mortem on the projects was executed in week 13 of the semesters, covering the discussion on empathy, ethics in communication, dealing with the peers and society, ethics in executing the projects, unethical conduct observed, risk and risk assessment, as well as the improvement that can be done for the next cohorts. All the activities for final assessments were marked and considered as individual programme outcome attainment. 


\section{Data Analysis}

The quantitative survey data were presented in percentages, while the qualitative data were analysed using content analysis and presented in categories. Apart from these, marks from continuous assessments such as essays, case studies, quizzes, and final assessment (proposals, portfolios and presentations) were also analyzed. Except for the quizzes, the rest of the assessments were assessed by using rubrics. Each of the rubrics was related to certain aspects of students' ethical conduct, while essays on personal values and case studies for individuals and groups were used to assess ethical spheres of controls i.e., students' personal and interpersonal control.

\section{RESULTS AND DISCUSSION}

\section{Students' Perceptions of the Previous Engineering Ethics Course}

Analysis on the perceptions of students on both the course content and methods of delivery are shown in Figure 2 for the previous EE course, whilst Figure 3 relates to the newly developed EE course based on Instructional Methods.

\section{Contents}

About $38.2 \%$ claimed that the content was very interesting, $21.8 \%$ claimed that it was fine for them, $37.8 \%$ mentioned that the content needed improvement, and the rest mentioned that it was a boring subject, as shown in Figure 2(a). On the same note, $80 \%$ of students claimed that the course contained an appropriate amount of both Islamic and technical perspectives, $13.2 \%$ mentioned it was imbued with very little Islamic perspective, while $7.8 \%$ said it was too technical, as depicted in Figure 2(b).

\section{Figure 2}

Students' Perceptions of the Contents of the Previous Engineering Ethics Course

(a)

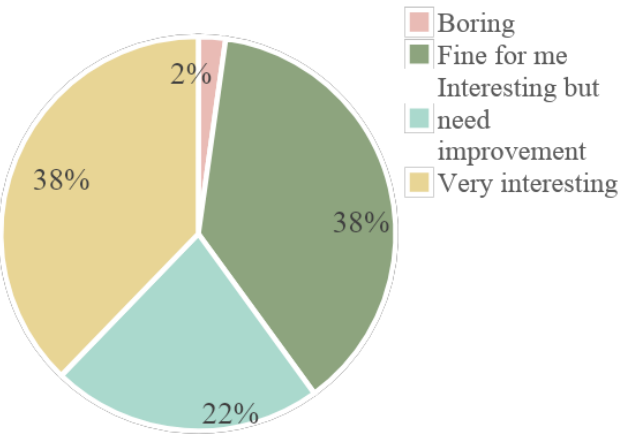

(b)

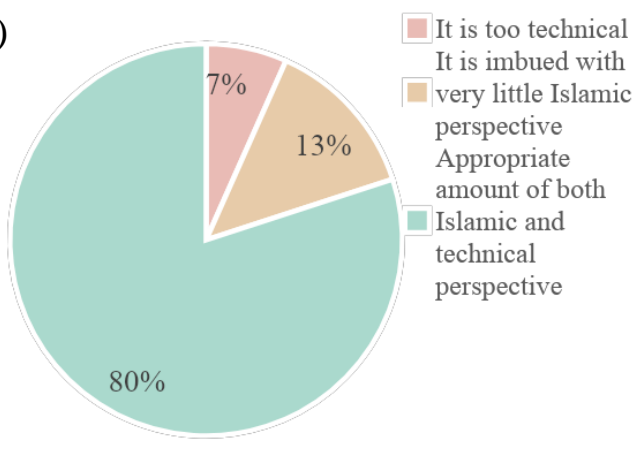




\section{Educators' Approaches}

About $43 \%$ of the respondents mentioned that the educator was able to blend the content of the engineering and Islamic perspective well. $31 \%$ mentioned that half of the subjects was similar to the university required subject UNGS 2050, while the other half was relevant to engineering. About 19\% mentioned that it was just like UNGS 2050 course, while 7\% said that it was similar to other UNGS courses (UNGS 2030 and UNGS 2040) as shown in Figure 3(a). However, none of the respondents claimed that it was too technical.

Concerning the course delivery, $78 \%$ of students had the perception that the educator delivered the subject well, blending the Islamic perspective and mainstream engineering, $20 \%$ mentioned that it was adequate from the Islamic perspective but less so in the mainstream engineering aspect, and only $2 \%$ bemoaned that it was too technical, so much so that they lost track of the Islamic perspective, as depicted in Figure 3(b).

\section{Figure 3}

Students' Perceptions of (a) Islamic and Engineering Content, and (b) Delivery Approaches of the Previous Engineering Ethics Course (GENE 4300)

(a)

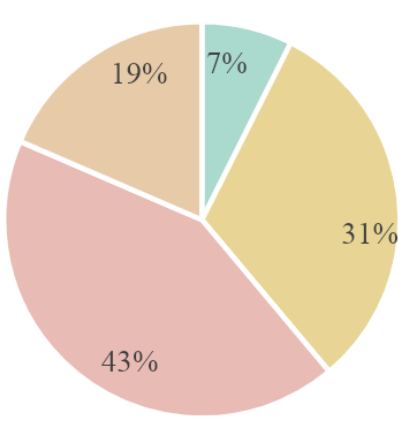

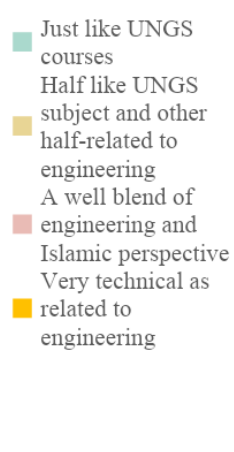

(b)

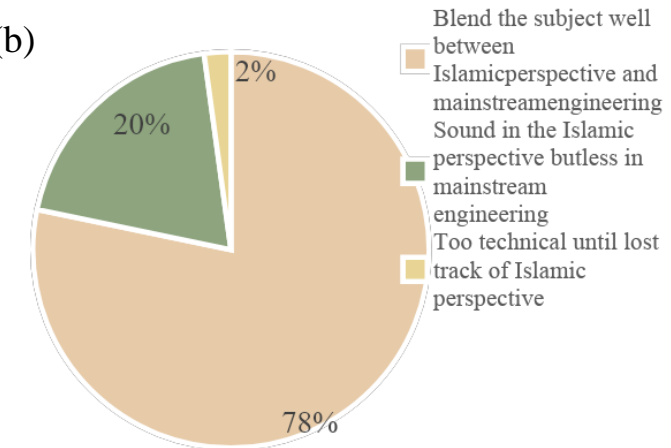

On the qualitative and open suggestion part of the survey, feedbacks from the students were quite similar, hence these were grouped into two categories of feedback, as presented in Table 3 . The students perceived the EE course as similar to UNGS 2050 and tend to generalize the former to the latter. In order to have a clear understanding of these perceptions, a deliberation on the UNGS 2050 course is offered. This course is a university required course that must be taken by all the students as a graduation requirement, and it is offered by the humanities faculty in IIUM, the Kulliyyah of Islamic Revealed Knowledge and Human Sciences (IRKHS). This course is normally taken at the early stage of the students' period of study, and consists of two parts, Islamic ethics and fiqh for everyday life. This course is intended to demonstrate to Muslims the importance and the role of ethics and fiqh in their daily lives. 
Table 3

Respondents' Qualitative Feedback on the Contents and Approaches of the Previous Engineering Ethics Course

\begin{tabular}{ll}
\hline \multicolumn{1}{c}{ Elements } & \multicolumn{1}{c}{ Qualitative Feedback } \\
\hline Contents & - Please cancel UNGS and this course. We need Matlab \\
& and Java class \\
& - More real; situation instead of facts \\
& - The content is not so bad for this course \\
& - Any slight improvement is enough \\
& The content is good; in order to be a good Muslim \\
& - It is like the UNGS \\
& - Eseed to have up-to-date content \\
\hline Teaching & - More hands-on applications rather than theories; More \\
approaches & case studies and discussions in groups rather than study \\
& from the slides \\
& - More activities instead of traditional class format \\
& Not very interesting. The lecturer/presenter only talk \\
& - We need what is in the slide
\end{tabular}

The main issues focused on in the first part of this course include the main Islamic ethical concepts, Islamic values and ethics for different professions, interpersonal ethics, whilst the second part includes an overview of Islamic fiqh and Islamic schools, a discussion of shari'ah criteria for measuring human needs and actions, a discussion of bioethical issues in medicine, and a discussion of family ethics in Islam. Even though both the two courses are mainly about ethics, they differ in the sense that the UNGS 2050 stresses on the theory and philosophical ethics, while the EE deals with ethics as engineers in the workplace, which includes codes of conduct and other elements relevant to the engineers. Due to the conventional instructional approach, and the perception of the students that this subject was not important for them, they lost the enthusiasm to focus on this subject. Since EE was previously taught by the educators from the same department using the same instructional strategies, the students assumed that the courses were alike.

The analysis undertaken from this simple qualitative survey indicate that the students looked forward to some differences in this ethics course. They anticipated something new and up to date with a dynamic approach involving some activities dealing with real-life situations. 


\section{Students' Perceptions of the Newly Developed Engineering Ethics Course}

The results obtained from the survey given to students are shown in Figure 4. There are increments of the student understanding on the content of the subject, up to $30 \%$, while $31 \%$ of the students claimed that the course was interesting, as shown in Figure 4(a) and Figure 4 (b), respectively.

\section{Figure 4}

Students' Perceptions of (a) Course Content, (b) Delivery Approach of the Newly Developed Engineering Ethics Course (GENE 4301), and (c) Comparison of Islamic and Engineering Elements

(a)

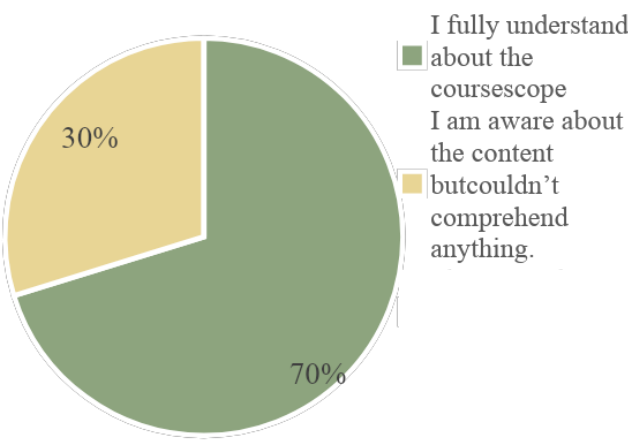

(c)

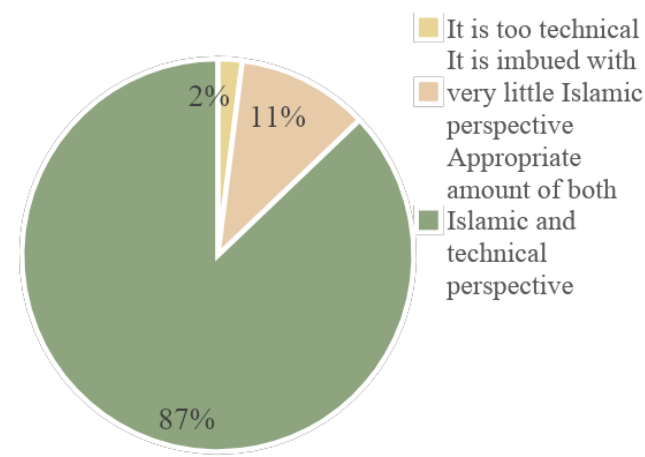

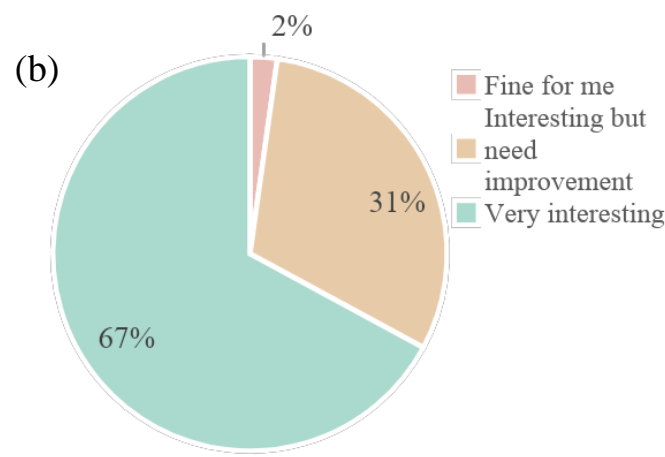

It is too technical It is imbued with very little Islamic perspective Appropriate mount of both technical

About $87 \%$ of the students perceived that the course has an appropriate amount of both Islamic and engineering elements, as shown in Figure 4 (c). Overall, Figure 4 (a), (b), and (c) show a higher percentage of students' positive perception of the new course content compared to the previous one. On the qualitative and open suggestion, feedback from the students is recorded in Table 4. 


\section{Table 4}

Respondents' Qualitative Feedback on the Contents and Approaches of the Newly Developed Engineering Ethics Course

\begin{tabular}{ll}
\hline \multicolumn{1}{c}{ Elements } & \multicolumn{1}{c}{ Qualitative Feedback } \\
\hline Contents & The content of the subject is good; we learn what needs and need \\
not be done. \\
- The content makes us understand better our journey as an engineer. \\
\hline Teaching & - The discussion on the real cases is an eye-opener. The subject is \\
Approaches & interesting when there is no final exam. \\
- & The sharing of the actual experience in the industry is good, and can \\
& communicate with the industry people as well. \\
- & Enjoy role play and debate and how the educator moderates it. \\
- & Preparing a video is taking too much time. \\
- I learn to voice out my opinion in the class. & The community service, even though it cannot be executed a \\
- hundred percent due to Covid-19, is good as we learn how to \\
contribute to the society \\
- Too much work on Community service, but I learn a lot of new \\
things as I am a manufacturing student and not familiar with \\
- Arduino, but my group members who are good at it have taught me \\
this.
\end{tabular}

Students' qualitative responses indicate that even though a lot of work needed to be done in the USR, the students had gained some good experience from it. It is also observed that they had to practice all the ethical conduct that had been discussed in the earlier semester and implement it in the USR. It is noted from the beginning of the project that educators had the chance to provide support and encouragement in enhancing students' competency to help achieve their professional excellence. Moreover, educators also encouraged students to accept the task as a personal duty and responsibility to keep up to date on emerging issues and potential problems.

There are, however, some drawbacks to having this USR. Time spent for the educators to guide and motivate the students to come up with high-impact projects as well as the rubric assessment for the proposal, portfolio, and presentations was demanding. In addition, the high 
number of students taking the subject, was burdensome to the educators of the subjects. Some discussion can be initiated to overcome these issues, whilst retaining the aspirational ethics embedded in the engineering ethics course to promote personal integrity.

\section{Students' Ethical Awareness and Behavior}

In the test run of the newly developed course, the students were given the task to write an essay on their personal values and complete two case studies individually and in groups. The majority (> 80\%) scored good marks, and only a small number of the students were not able to come up with concrete good personal values. Multiple choice questions (MCQ) for attributes of engineers and ethics for engineers were given as quizzes; the students attained moderate results within the range of 75- 85\%, as shown in Figure 5(a). The case study, which was completed individually (CSI), and needed to be solved on the spot, was aimed to evaluate students' ability in making an ethical decision within a limited time. Meanwhile, the case study completed in groups (CSG) was to prepare students in working cooperatively and actively within a longer deadline. As expected, a majority of the marks for the individual case study were slightly lower compared to the group case study. However, there were some isolated cases where individuals obtained higher marks in the individual case study. The quizzes, essays and case study were formative assessments, and made up the continuous assessment mark. These assessments were still under the ethical awareness stage.

On the other hand, the university social responsibility (USR) project under the aspirational ethics were the activities that assessed the affective domain of the students, the ethical behavior. Figure 5(b) shows some distribution of results for the overall final assessment comprising proposals, portfolio and presentations. As for the continuous assessment, in the ethical awareness stage, most of the students were in the moderate range of $76 \%$ to $85 \%$. The rubrics for the three components evaluated the ethical behaviors of the students in terms of honesty, responsibility, respect and fairness, together with other elements such as leadership and communication.

\section{Figure 5(a)}

Percentages of Students' Scores for Continuous Assessment

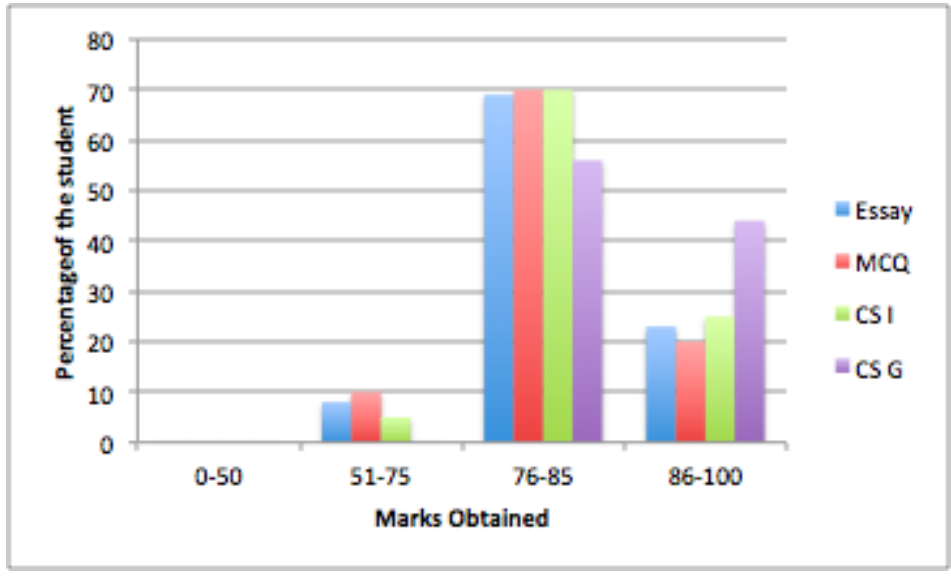




\section{Figure 5(b)}

Percentages of Students' Scores for the University Social Responsibility (USR) Project

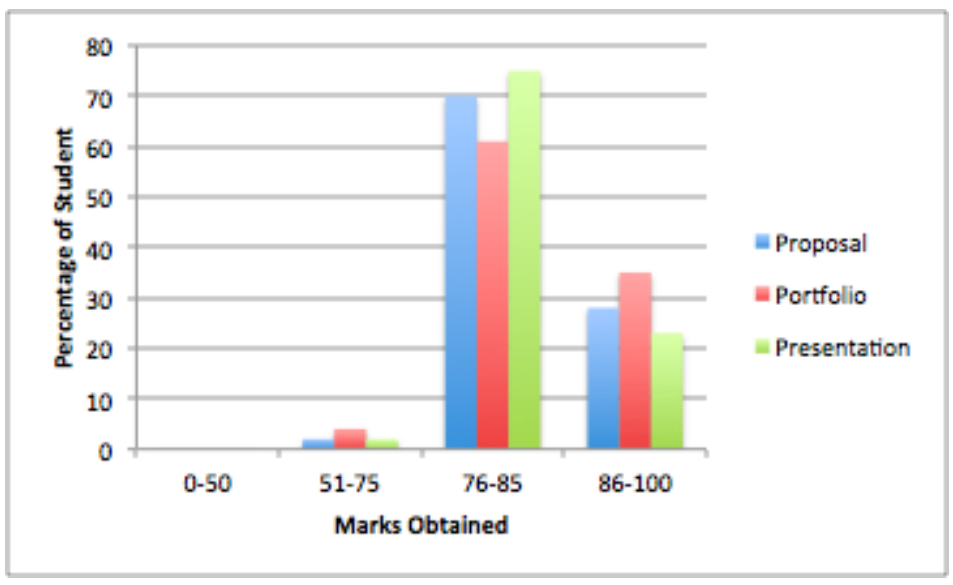

The framework establishes an opportunity for the strategic use of essays on personal values and case studies for spheres of control. Understanding the behavior within the spheres of control will most likely predict the behavioral intentions and actual behavior. Nevertheless, different types of control such as personal and interpersonal control, show different outcomes for a given moral dilemma. Additionally, it is important to recognize that real ethical choices may contradict those made in hypothetical situations.

Multiple choice questions quiz was the format offered for students to deal with difficult ethical dilemmas involving a diversity of moral codes resulting from culture, education, and background differences. It could also be useful to understand how different areas of control are involved in ethical dilemmas, in order to understand how these differences, affect the decisionmaking process under both hypothetical and real circumstances. 


\section{CONCLUSION}

The framework and instructional methods shared in this article is developed for the engineering students in $\mathrm{KoE}$ to be able to internalize their roles and responsibilities towards the Creator and society, comprehend Islamic ethical values on safety and health, as well as environmental concerns, and the need for sustainable development; additionally, to demonstrate ethical principles in leadership, behavior and character with continuous self-development. Also developed is a model that aims to predict both engineering students' ethical awareness, as well as how they will act upon this awareness, to serve as a teaching tool for courses that address engineering ethics. When developing pedagogy to teach ethical awareness and behavior effectively, it is crucial to understand how decision-making processes and motivational variables influence ethical decisions. As part of preparing students for career opportunities in engineering, the instructional strategy used can easily be translated into classroom activities and assessments that emphasize developing students' understanding of professional and ethical responsibilities in addition to building on their professional identities.

This paper's intended purpose is neither to critique existing approaches to the teaching of engineering ethics nor to provide an immediate solution to the question of how to better prepare student engineers for ethical behavior. In fact, it is intended to offer a different approach to help improve engineering ethics education, by adding to the collective efforts of many.

\section{ACKNOWLEDGEMENT}

The authors would like to acknowledge the Kulliyyah of Engineering for giving the freedom to embrace a new teaching approach and the students for participating in the research. 


\section{REFERENCES}

A Workshop on Ethics and Engineering Education. (2019). "Meeting the Challenges of Engineering Ethics Education”, TU/Eindhoven, the Netherlands, 12 - 13 December 2019

Ahmad, A. M., Hussin, Z., Yusof, F., Mohd Jamil, M. R., Shahri, M. H. \& Ishak, M. K. (2017). Level of Ethical Behavior among Engineering Students: Polytechnic Malaysia. Journal of Human Development and Communication, 6, 1-17.

Bairaktarova, D. \& Woodcock, A. (2016). Engineering Student's Ethical Awareness and Behavior: A New Motivational Model. Science and Engineering Ethics, 23(4), 11291157. https://doi.org/10.1007/s11948-016-9814-X

Balakrishnan, B. (2016). Engineering Ethics Education. Leadership and Personnel Management, 1383-1393. https://doi.org/10.4018/978-1-4666-9624-2.ch061

Balakrishnan, B., Tochinai, F. \& Kanemitsu, H. (2018). Engineering Ethics Education: A Comparative Study of Japan and Malaysia. Science and Engineering Ethics, 25(4), 10691083. https://doi.org/10.1007/s11948-018-0051-3

Basart, J. M. (2015). Teaching Engineering Ethics in the Classroom. Advances in Civil and Industrial Engineering, 144-158. https://doi.org/10.4018/978-1-4666-8130-9.ch011

Borhan, L., Azman, A.W., Mat Ghani, G., Abdullah, M.F., Rahman, Z.A. \& Yusof, Z.M. (2021). International Islamic University Malaysia (2021). Sejahtera Academic Framework: Humanising education for Rahmatan lil-Alamin post-COVID-19 disruption. Editor f. ISBN 978-967-467-018-4.

Bruce, P. \& Roli, V. (2001). Teaching engineering Ethics, Proceedings of the 2001 American Society for Engineering Education Annual Conference \& Exposition Copyright 2001, American Society for Engineering Education.

Clancy, R. F., Zheng, G. \& Hung, D. L. (2016). An empirical, comparative approach to engineering ethics (education) in international and cross-cultural contexts A study concerning Chinese engineering students' knowledge of and views concerning contents and concepts related to engineering ethics. In 2016 June, ASEE International Forum.

Criteria for Accrediting Engineering Technology Programs (2020). American Board of Engineering and Technology (ABET) 2020-2021.

Engineering Accreditation Council (EAC) (2020). Engineering Programme Accreditation Standard 2020 (Manual).

Harding, T. S., Carpenter, D. D. \& Finelli, C. J. (2013). Two Years Later: A longitudinal look at the impact of engineering ethics education. In 2013 ASEE Annual Conference \& Exposition (pp. 23-1272).

Harris, C. E. (2013). Engineering ethics: From preventive ethics to aspirational ethics. In Philosophy and engineering: Reflections on practice, principles and process (pp. 177187). Springer, Dordrecht. 
Herkert, J. (2001). Guest editors' introduction - Engineering ethics: continuing and emerging issues.II. Education. IEEE Technology and Society Magazine, 20(4), 4-5. https://doi.org/10.1109/mtas.2002.974501

Kiser, A. I. T., Morrison, E. E. \& Craven, A. (2009). The Application Of Kohlbergs Moral Development Model To College Students Technology Ethics Decisions. Journal of College Teaching \& Learning (TLC), 6(5).

Lawson, R. A. (2004). Is Classroom Cheating Related to Business Students' Propensity to Cheat in the "Real World"? Journal of Business Ethics, 49(2), 189-199. https://doi.org/10.1023/b:busi.0000015784.34148.cb

Loendorf, W. (2009). The case study approach to engineering ethics. In 2009 Annual Conference \& Exposition (pp. 14-1182).

Miñano, R., Uruburu, N., Moreno-Romero, A. \& Pérez-López, D. (2016). Strategies for Teaching Professional Ethics to IT Engineering Degree Students and Evaluating the Result. Science and Engineering Ethics, 23(1), 263-286. https://doi.org/10.1007/s11948015-9746-X

Ozaktas, H. M. (2011). Teaching Science, Technology, and Society to Engineering Students: A Sixteen Year Journey. Science and Engineering Ethics, 19(4), 1439-1450. https://doi.org/10.1007/s11948-011-9329-4

Rodzalan, S. A. \& Saat, M. M. (2016). Ethics of Undergraduate Students: A Study in Malaysian Public Universities. International Journal of Information and Education Technology, 6(9), 672-678. https://doi.org/10.7763/ijiet.2016.v6.772

Stockton-Tillman, K. J. (2017). The Relationship of Moral Reasoning and Ethical Decision Making Among IT Employees (Doctoral Dissertation, Walden University).

Weil, V. (2003). Ethics across the curriculum: Preparing engineering and science faculty to introduce ethics in their teaching. In Emerging technologies and ethical issues in engineering: Papers from a workshop, pp. 79-93.

Wijesinghe, D. P. S. \& Jayawardane, V. P. T. (2018) Perception of Engineering Students towards the importance of Engineering Ethics for their future Profession.

Zoltowski, C. B., Cummings, A. T. \& Oakes, W. C. (2014). Immersive community engagement experience. In 2014 ASEE Annual Conference \& Exposition, pp. 24-689. 